ISSN 0103-5150

Fisioter. Mov., Curitiba, v. 29, n. 1, p. 37-47, Jan./Mar. 2016

Licenciado sob uma Licença Creative Commons

DOI: http://dx.doi.org.10.1590/0103-5150.029.001.A003

\title{
Reflections on the Production of the Formation of Physiotherapy in the Con-text of SUS
}

\author{
A produção de reflexões sobre a formação dos \\ Fisioterapeutas no contexto do SUS
}

Ana Luísa Pinho Pinto Ferreira, Mônica De Rezende*

Fundação Instituto Oswaldo Cruz, (FIOCRUZ), Rio de Janeiro, RJ, Brazil

\begin{abstract}
Background: This study was motivated by the need of understanding how the relationship of the training with the national health system is treated, both in the sphere of health services and the aca-demic area. This work aims to contribute to the debate on the inclusion of the physiotherapist in SUS (Brazil's NHS) by pointing out issues that need to be deepened in future studies. Purpose: To analyze the national literature production on the relationship between the training of therapists and their work in SUS, from 1996 to 2010. Methods: Descriptive research with literature on the bases: LILACS, SCI-ELO Bank and CAPES thesis. Results: We found 13 publications, sorted by: year, publication type, region where it was published in the categories "national curriculum guidelines," "professional respon-sibility", "integrality in health" and "conceptions of teachers in training in Physiotherapy ". There no publishing from 1996 to 2005, gradually increasing from this year. It was identified a higher number of articles compared to other types of publications; there is also an important difference between the Brazilian regions, with higher prevalence of studies in the South $(53.8 \%)$ and a greater number of pub-lications in the category "national curriculum guidelines". Conclusion: It was possible to raise ques-tions that involve the applicability of the National Curriculum Guidelines on the pedagogical courses; suitability of teachers to the reality of SUS; investigation
\end{abstract}

*ALP: grad, e-mail: analuisapinho@yahoo.com.br MDR: PhD, e-mail: m.rezende70@gmail.com 
of the models covered in health care envi-ronments trainers, and the lack of contribution by higher education institutions on teaching-research and teaching and public service, contributing to form an important agenda of study.

Keywords: Physical therapy specialty. Unified health system. Human resources formation.

\section{Resumo}

Contextualização: Este estudo foi motivado pela necessidade de compreender como a relação da formação dos profissionais com o sistema nacional de saúde é tratada, tanto na esfera dos serviços de saúde quanto no espaço acadêmico. Almeja contribuir para o debate sobre a inserção do fisioterapeuta no SUS ao apontar questões que precisam ser aprofundadas em estudos futuros. Objetivo: Analisar a produção bibliográfica nacional sobre a relação entre a formação de fisioterapeutas e sua atuação no SUS, no período de 1996 a 2010. Métodos: Pesquisa descritiva, com levantamento bibliográfico nas bases: LILACS, SCIELO e Banco de teses CAPES. Resultados: Foram encontradas 13 publicações, classificadas por: ano, tipo de publicação, região em que foi publicada e pelas categorias "diretrizes curriculares nacionais", "responsabilidade do profissional", "integralidade em saúde" $e$ "concepções dos docentes na formação em Fisioterapia". Não houve publicação desde 1996 até 2005, ocorrendo aumento progressivo a partir deste ano. Identificou-se maior quantidade de artigos em relação aos outros tipos de publicações; importante diferença entre as regiões brasileiras, com maior prevalência de estudos no Sul (53,8\%); e um maior número de publicações referentes à categoria "diretrizes curriculares nacionais". Conclusão: Foi possivel levantar questões que giram em torno da aplicabilidade das Diretrizes Curriculares Nacionais nos projetos pedagógicos dos cursos; adequação dos docentes à realidade do SUS; investigação dos modelos de atenção à saúde abordados nos ambientes formadores; e a carência de contribuição das Instituições de Ensino Superior de cunho particular na articulação ensino-pesquisa e ensino-serviço público, contribuindo para formar uma importante agenda de estudo.

Palavras-chave: Fisioterapia. Sistema Único de Saúde. Formação de recursos humanos.

\section{Introduction}

Since the Third National Health Conference, in 1963 , the training of professionals is seen as a relevant issue in discussions about the formulation of public policies for the health area. In the current situation, the concern with the formation in line with the guidelines and principles of the health system is based on the need to adapt to changes in brazilian's demographic and epidemiological profiles in order to meet the real health needs of the population (1).

Physiotherapy as higher education profession was regulated in Brazil in 1969, by Decree-Law No. 938, and since then, assures the professional execution methods and therapeutic techniques in order to restore, develop and retain the health of the patient (2). With activities surrounding health care, direction and supervision within services and teaching, Physiotherapy progressed over the years, a fact that was revealed by expanding the supply of undergraduate courses, numerous professional insertion in the labor market and a consequent increase in their field $(3,4)$.

Despite that the profession origin is described by the need to give an answer to society around the excessive cases of polio and numerous industrial accidents highlighted in the country $(5,6,7)$, currently Physiotherapy is seen as a profession that can not only work in the rehabilitation of diseases, but also promote and protect health. The role of a physiotherapist in primary care can be understood as the contribution of another professional in health care teams, allowing different looks, expanding the innovative possibilities of care practices and increasing the potential of solving (8). Concerning people's health, physical therapy approaches the National Health System (SUS) in order to share an expanded concept of health. This way of understanding health begins to consolidate in Brazil, even in the 1970s, through the Sanitary Reform movement, which along with events held in the following 
years, admitting health as a social right, work in the constitution of the Brazilian health system $(9,10)$.

SUS as a national health system, regulated by the Organic Law No. 8080 and No. 8142 of 1990 deals with health actions, organization and operation of services in the form of principles and guidelines (11, 12). Through SUS, health actions aimed at intervening in living conditions, with the aim of improving the quality of life.

With a new way to understand the health of population, the discussion about the training of health professionals is fundamental. Thus, higher education institutions (IES) in health emerge as an important instrument for the actions of SUS. In order to provide the approach of higher education to SUS designs, since 2000, the guidelines for undergraduate courses are guided by the National Curriculum Guidelines (DCN), which proposes the increasing of the ability of autonomy and discernment of future professionals seeking comprehensive care and quality and humanization of care provided to individuals, families and communities (13).

DCN, as well as SUS guidelines and changing movements in the training of health professionals, bring the perspectives of the existence of IES committed to issues of social relevance $(14,15)$. The DCN for Physiotherapy courses feature not only an orientation to the IES, but also a path that puts the physiotherapist in public health services in a comprehensive and humane way, proposing changes in its operations (16). Brings thus major challenges to social actors involved in the training, including universities, teachers, those responsible for policy formulation and the students themselves.

The motivation for this study arises from the need to understand how the relationship of the training of professionals with the national health system is being treated, both in the sphere of health services and in the academic area. Thus, this study aimed to analyze the national bibliographic production that deals with the relationship between the training of physiotherapists and its performance in SUS, in the 1996-2010 period.

This analysis sought from the qualification of bibliographical production found, to point out the number of publications, the type - article, dissertations, theses, etc. - the institutions and prioritized magazines and the issues addressed. As a result, it was possible to make considerations and raise questions for reflections to be deepened in future studies.

\section{Methods}

This study is characterized as a literature research, which for Deslandes et al (17) "allows articulating concepts and systematize the production of a particular area of knowledge, creating new issues in a process of development and overcoming of what is already produced."

Initially, it sought to understand the guidelines for higher education in Physical Therapy and the relationship of its training with SUS. Then began a literature search process in order to identify national publications that addressed this relationship in the period 1996 to 2010. The choice of 1996 was due to Law No. 9.394 of December 20,1996, which deals with the basic guidelines of national education (LDB) (18).

For the bibliographic research, we chose the databases of national and Latin coverage data, as the research's aim is to identify national publications that discuss the theme. Selected bases were: LILACS (Latin American and Caribbean Health Sciences), SciELO (Scientific Electronic Library Online) and the Bank of Capes theses. Such bases were chosen because they have a vast bibliographic index, consisting of important periodic on education and health. It was observed that most of publications found on the subject were academic papers, monographs, dissertations and theses, which justified the choice of the Bank of Capes theses. The keywords used were: training, physiotherapy, SUS and graduation.

After the identification of such publications, they were analyzed, taking into consideration the following elements: keywords, title, database searched, year of publication, types of publications (article, thesis, dissertation or thesis), federal units, regions and institutions where they were held, job objective and the main issues raised in the summary. Such elements were classified, systematized and organized into charts and tables that allowed the qualification of the selected production.

As a way of analyzing raised publications, it was made a careful study of the summaries, which we tried to work through the issues that were more evident and indicated more frequently in these readings. This set of issues can be divided into four major analytical categories:

1) National curriculum guidelines: speak of the application of the guidelines in the training of physiotherapists; 
2) Professional responsibility: discusses the responsibility of the profession and physiotherapists in changing the training approach, as well as compliance with the resolutions of Physiotherapy bodies with policies and programs that encourage oriented training to SUS molds;

3) Integrality in Health: discusses training guided in the complexity of human beings, as well as training in physical therapy from the perspective of completeness - as one of the principles of SUS;

4) Conceptions of teachers in training physiotherapists: talk about the training of teachers for teaching Physiotherapy linked to the precepts of SUS.

\section{Results}

13 publications were found in total. All dating from the year 2005 . There was a progressive increase

Table 1 - Number of publications on the relationship between the training of physiotherapists and its performance in SUS, the second year of publication

\begin{tabular}{lcc}
\hline \multicolumn{1}{c}{ Year } & $\begin{array}{c}\text { Number of } \\
\text { publications }\end{array}$ & $\%$ \\
\hline $\mathbf{1 9 9 6}$ a 2004 & 0 & 0 \\
$\mathbf{2 0 0 5}$ & 1 & 7.7 \\
$\mathbf{2 0 0 6}$ & 1 & 7.7 \\
$\mathbf{2 0 0 7}$ & 2 & 15.4 \\
$\mathbf{2 0 0 8}$ & 2 & 15.4 \\
$\mathbf{2 0 0 9}$ & 3 & 23 \\
$\mathbf{2 0 1 0}$ & 4 & 30.8 \\
Total & 13 & 100 \\
\hline
\end{tabular}

Note: Source: Prepared

in the number of publications, reaching 4 in 2010, $30.8 \%$ of the total (Table 1).

Of the 13 publications, seven were scientific articles (about $53.8 \%$ of the total), 1 monograph, 4 dissertations and one book chapter.

Regarding the articles published, there was a predominance of publications in scientific journals that address specific issues of the field of physical therapy: Physical Therapy in Movement, Physical Therapy and Research, and Physiotherapy Brazil. Only one of the works was published in the journal Science and Public Health, published by the Brazilian Association of Graduate Studies in Public Health (ABRASCO). About the magazines in the physiotherapy area, two of them are publications of healthcare courses of educational institutions: a physiotherapy course at the Pontifícia Universidade Católica do Paraná and one from Faculdade de Medicina da Universidade de São Paulo, public and private, respectively.

In clearing the institutions in which scientific papers were produced (thesis and dissertations), there is the absence of private universities as institutional source of publications found. Two federal agencies and three state were located: Escola de Saúde Pública do Rio Grande do Sul, Universidade Estadual de Londrina, Universidade Federal de São Paulo, Universidade do Vale do Itajaí e Universidade Federal do Rio Grande.

Regarding the regions of the country, it was observed significant prevalence of studies in the South, totaling 7 publications (53.8\%). The other is presented as follows: 2 in the Southeast (15.4\%), second in the Midwest (15.4\%), one in the Northeast (7.7\%) and none in the North. In one of the analyzed publications it was not possible to obtain such information (Figure 1).

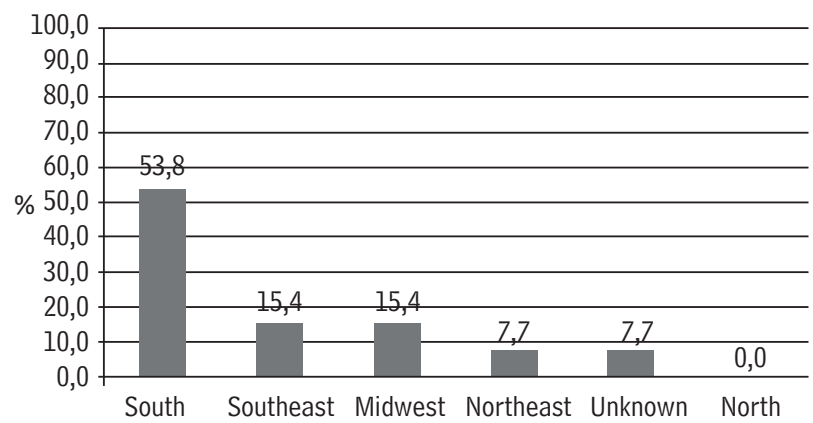

Figure 1 - Percentage distribution of publications on the relationship between the training of physiotherapists and its performance in SUS in the regions of Brazil $(n=13)$ Note: Source: Prepared

Table 2 shows the number of publications found for each category of analysis. Note that the category "national curriculum guidelines," is evident when compared to other categories $(33,3 \%)$. 
Table 2 - Number of publications on the relationship between the training of physiotherapists and its performance in SUS, according to the established categories of analysis

\begin{tabular}{|c|c|c|}
\hline $\begin{array}{c}\text { Categories of } \\
\text { analysis }\end{array}$ & $\begin{array}{l}\text { Number of } \\
\text { publications }\end{array}$ & $\%$ \\
\hline DCN & 6 & 33.3 \\
\hline $\begin{array}{l}\text { Professional } \\
\text { Liability }\end{array}$ & 4 & 22.2 \\
\hline $\begin{array}{l}\text { Integrality in } \\
\text { Health }\end{array}$ & 5 & 27.7 \\
\hline $\begin{array}{l}\text { Conceptions of } \\
\text { teachers }\end{array}$ & 3 & 16.6 \\
\hline Total & $18^{*}$ & 100 \\
\hline
\end{tabular}

Note: Source: Prepared

\section{Discussion and Conclusion}

The evidence of the few papers on this topic is regarded as one of the results to be thought out and studied in the debate about higher education in physiotherapy. Considering that college students are interested in studying what the labor market points out as promising points (8), the straight relation to SUS has not proven attractive to this profession. Physiotherapy has as a privileged market niche private clinics of private care and the relationship with SUS has been established, in most cases, through agreements. The demand for expertise in public health or graduate to discuss the issue addressed in this article is still small, although it has shown increasing in recent years.

The abstracts surveyed suggested a relationship between the years of its publications and the period from the imposition of DCN in 2002. This indicates that the discussion on the new guidelines for the training of health professionals produced a booster effect on physiotherapists who were looking or started to look at public health as a performance and research field. It should be noted that the publication identified in 2005 was a master's thesis, which is relevant, given that the publication of a dissertation in a given year means the beginning of a study two years earlier. Thus, if we consider the approval of DCN for Physiotherapy in 2002 , it is clear that the interest in discussion in this case started soon after.
Note that, although there has been significant growth in the number of courses from the second half of the 1990 s - about $80 \%$ increase $(3,4)$, there was not, at that time, publications on the discussion of training in Physical Therapy and its relationship with SUS. This finding highlights the importance of reflecting, these days, about physiotherapy position in the health system consolidation: where the profession want to take place in the proposals of SUS? It is clear the space that is opening, since the implementation of Centers of Support for Family Health (NASF) for the physiotherapist's entry into SUS, in the first level of attention. However, there is a lack of knowledge about this field of work by professionals and an unpreparedness to deal with the proposals and work processes of this new field. There seems to be also a detachment of corporate institutions in the category in encouraging this discussion in general and specifically within the educational projects of educational institutions.

It was identified a lack of doctoral theses on the relationship between the formation in Physiotherapy and the health system in the selected time period for the research. This fact corroborates the finding of some authors that there is a predominance of biological areas in the training of physical therapy researchers (19). This encourages reflection on the lack of research in the area of Physiotherapy of Public Health, which becomes relevant as it notes the establishment of a growing area of action, which is SUS setting with many aspects to be discussed and with great need for multidisciplinary participation.

According to Coury and Vilella (19), most physical therapy researchers choose private universities as area of operation, with few professionals who fixate on government agencies or research institutes. However, it was not identified scientific papers linked to private institutions. Thus, despite the number of researchers concerned with the issues of Physiotherapy inserted into organs or public research institutes being smaller, it is they who are producing on the relationship between the formation of the physiotherapist and its performance in SUS. This reveals the importance of investigating the relationship 'public and private higher education institutions versus health care model used as a reference for professional practice'. What interests these models of care attend to? What about the health conceptions? These issues are close to the assertions of some authors, 
when talking about the importance of the analysis of the selected content for health training courses (20).

In considering the Federative Regions, beyond territorial, social and economic differences are also highlighted differences in education and health services offerings, and this may be related to the data found in this study. An issue to be discussed further is the relationship of social and scientific development with the number of publications found, bringing out important elements such as greater access to incentive grants, training programs, etc.

It is noteworthy that, regarding the place of publishing of journals, it was noted that 3 of the 4 magazines are edited in the Southeast region, while the other is being edited in the South. This fact leads to the question about the need to promote forms for encouraging scientific publishers from different regions, as regards the contribution of dissemination of research in the area of physical therapy and other health areas.

From the analysis of the established categories, the category "national curriculum guidelines" is evident when compared to the others, although still in insignificant number. The slightly raised debate leads us to some important questions to understand this scenario: where and whom DCN were discussed with for physical therapy area; there was a broader involvement of professionals and IES; the professionals identify the importance of these guidelines in their training process; there was concern by the representative bodies of the category on clarifying this matter.

Whereas despite little publication, there is a debate going on about the inclusion of DCN to health in environments trainers, one must question how is the application of DCN. Authors state that despite efforts brought by DCN and councils and associations linked to the health professions, new directions appear to be necessary for changes in the training of professionals suitable to the reality of comprehensive health care, as an indication of clear policies by SUS, being able to move beyond declarations of intent and formal existence of proposals, with the possibility of offering real interference in vocational training processes (21).

Despite the category "conceptions of teachers in training in Physiotherapy" present fewer publications, it is characterized as a key category for the relationship with SUS, due to the multiplier potential of the teaching profession itself. One must think about the need to promote common spaces of reflections in IES as a way of working with these professionals
SUS proposals and institute the exercise of criticism of their own institutional territories (22). Several issues can then be highlighted, providing a possible work schedule and study: how is the training of these teachers; what is their understanding of DCN; what knowledge they have about SUS; how they understand the relationship of specialty with the health system; and how they articulate the various areas of knowledge in comprehensive care perspective.

The relationship between the education of health professionals and SUS must be thought and rethought by several people and agencies that contribute to the improvement of undergraduate health in the country. This research sought through bibliographic skills, to raise questions that need to be deepened, as well as contributing to "put ellipsis and propose issues that can assist other works" (7); in an attempt to enhance the much needed discussion on the relationship between SUS and higher education in physiotherapy.

\section{Acknowledgements}

Teachers Fernando Manuel Bessa Fernandes and Fábio Batalha Monteiro de Barros Battle for the valuable contribution in this research.

\section{References}

1. Ceccim RB, Carvalho YM. Ensino da saúde como projeto da integralidade: a educação dos profissionais de saúde no SUS. In: Pinheiro R, Ceccim RB, Mattos RA. (Org.). Ensinar Saúde: a integralidade e o SUS nos cursos de graduação na área da saúde. Rio de Janeiro: IMS / UERJ: CEPESQ: ABRASCO. 2006: 69-92.

2. Decreto-Lei n. 938, de 13 de outubro de 1969. Provê sobre as profissões de fisioterapeuta e terapeuta ocupacional, e dá outras providências. Brasília; 1969.

3. Bispo Júnior JP. Formação em Fisioterapia no Brasil: reflexões sobre a expansão do ensino e os modelos de formação. História, Ciências, Saúde. 2009;16(3) jul-sept: 655-68.

4. Pereira LA, Almeida M, Fisioterapia. In: Dinâmica das graduações em saúde no Brasil: subsídios para uma política de recursos humanos. Brasília: Ministério da Saúde, 2006. 
5. Rebelatto JR, Botomé SP. Fisioterapia no Brasil: fundamentos para uma ação preventiva e perspectivas profissionais; 1999.

6. Barros FBM. A formação do fisioterapeuta na UFRJ e a profissionalização da fisioterapia. [dissertation]. Rio de Janeiro: Instituto de Medicina Social, Universidade do Estado do Rio de Janeiro; 2002.

7. Freitas MS. A Atenção Básica como Campo de Atuação da Fisioterapia no Brasil: as Diretrizes Curriculares resignificando a prática profissional. [thesis]. Rio de Janeiro: Instituto de Medicina Social, Universidade Estadual do Rio de Janeiro; 2006.

8. Rezende M, Moreira MR, Filho AA, Tavares MFL. A equipe multiprofissional da 'Saúde da Família': uma reflexão sobre o papel do fisioterapeuta. Ciência \& Saúde Coletiva. 2009; 14(Supl. 1): 1403-10.

9. Paim, JS. O que é o SUS (Coleção Temas em Saúde). Rio de Janeiro: FIOCRUZ; 2009.

10. Baptista TWF. História das políticas de saúde no Brasil: a trajetória do direito à saúde. In: Matta GC, Pontes ALM (Org.). Políticas de saúde: a organização e a operacionalização do Sistema Único de Saúde. Rio de Janeiro: EPSJV / FIOCRUZ. 2007:29-60.

11. Lei no 8.080 de 19 de setembro de 1990. Dispõe sobre as condições para a promoção, proteção e recuperação da saúde, a organização e o funcionamento dos serviços correspondentes e dá outras providências. Brasília; 1990.

12. Lei no 8.142 de 28 de dezembro de 1990. Dispõe sobre a participação da comunidade na gestão do Sistema Único de Saúde (SUS) e sobre as transferências intergovernamentais de recursos financeiros na área da saúde e dá outras providências. Brasília; 1990.

13. Ministério da Educação. Conselho Nacional de Educação. Parecer CNE/CES no 1210/2001. Diretrizes Curriculares Nacionais dos Cursos de Graduação em Fisioterapia, Fonoaudiologia e Terapia Ocupacional. Brasília; 2001.

14. Pinheiro R, Ceccim RB. Experienciação, formação, cuidado e conhecimento em saúde: articulando concepções, percepções e sensações para efetivar o ensino da integralidade. In: Pinheiro R, Ceccim RB, Mattos RA. (Org.). Ensinar Saúde: a integralidade e o SUS nos cursos de graduação na área da saúde. Rio de Janeiro: IMS / UERJ: CEPESQ: ABRASCO; 2006:13-35.
15. Ceccim RB, Feuerwerker LCM. Mudança na graduação das profissões de saúde sob o eixo da integralidade. Cad. Saúde Pública. 2004;20(5):1400-10.

16. Conselho Nacional de Educação. Câmara de Educação Superior. Resolução CNE/CES 4, de 19 de fevereiro de 2002. Institui Diretrizes Curriculares Nacionais do Curso de Graduação em Fisioterapia. Brasília; 2002.

17. Deslandes SF, Neto OC, Gomes R, Minayo MCS (Org.). Pesquisa Social: Teoria, Método e Criatividade. Petrópolis: Vozes; 1994:52-3.

18. Lei no 9.394 de 20 de dezembro de 1996. Estabelece as diretrizes e bases da educação nacional. Brasília; 1996.

19. Coury HJCG, Vilella I. Perfil do pesquisador fisioterapeuta brasileiro. Rev. Bras. Fisioter. 2009; 13(4):356-63.

20. Saippa-Oliveira G, Koifman L, Pinheiro R. Seleção de conteúdos, ensino-aprendizagem e currículo na formação em saúde. In: Pinheiro R, Ceccim RB, Mattos RA. (Org.). Ensinar Saúde: a integralidade e o SUS nos cursos de graduação na área da saúde. Rio de Janeiro: IMS / UERJ: CEPESQ: ABRASC; 2006:205-27.

21. Da Silva DJ, Da Ros MA. Inserção de profissionais de fisioterapia na equipe de saúde da família e Sistema Único de Saúde: desafios na formação. Ciência \& Saúde Coletiva. 2007;12(6):1673-81.

22. Guizardi FL, Stelet BP, Pinheiro R, Ceccim RB. A formação de profissionais orientada para a integralidade e as relações político-institucionais na saúde: uma discussão sobre a interação ensino-trabalho. In: Pinheiro R., Ceccim RB, Mattos, RA. (Org.). Ensinar Saúde: a integralidade e o SUS nos cursos de graduação na área da saúde. Rio de Janeiro: IMS / UERJ: CEPESQ: ABRASC0; 2006:153-77.

Recebido: 06/08/2012

Received: 08/06/2012

Aprovado: $19 / 06 / 2015$ Approved: 06/19/2015 
